\title{
MOMENTARY LAPSES OF REASON: THE PSYCHOPHYSICS OF LAW AND BEHAVIOR
}

\author{
James Ming Chen ${ }^{*}$ \\ 2016 MiCH. ST. L. REV. 607 \\ TABLE OF CONTENTS
}

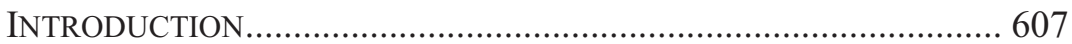

I. The CONVEntional CAPITAL AsSET PRICING MODEL ......... 608

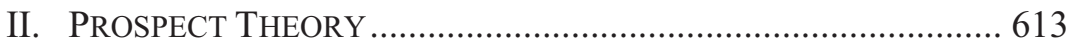

III. A Four-MOMENT CAPITAL ASSET PRICING MODEL .............. 618

IV. SKEWNESS PREFERENCE AND THE LONGING FOR

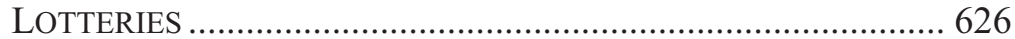

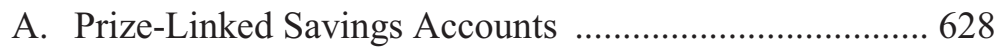

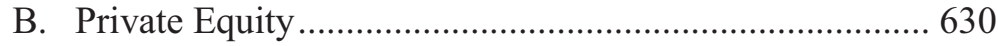

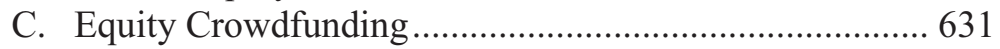

D. The Underpricing of Conglomerates...............................634 634

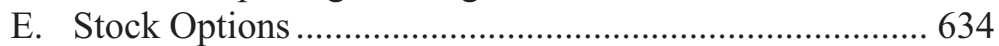

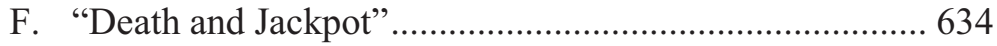

V. Initial Public OfFERINGS AS A SPeCial CASE...................... 637

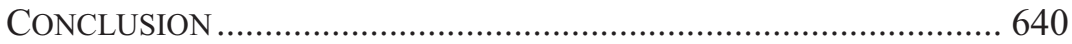

\section{INTRODUCTION}

The conventional capital asset pricing model (CAPM) remains the preferred approach to risk management in a wide range of economic settings. At the same time, the neoclassical assumptions underlying the CAPM have come under severe attack by behavioral economics. In sharp contrast with the purely rational agents of neoclassical economics, real humans make decisions under the constraints imposed by their innate heuristics. The tension between conventional asset pricing theory and behavioral economics puts particular pressure on law. As an applied branch of social science,

* Justin Smith Morrill Chair in Law, Michigan State University; Of Counsel, Technology Law Group of Washington, D.C. Christian Diego Alcocer Argüello and Barbara Bean provided very capable research assistance. Seth J. Chandler, R. Thorne McCarty, and Ted Sichelman provided very useful comments. Special thanks to Heather Elaine Worland Chen. 
law purports to subject human conduct to rules that should optimize objective well-being as well as subjective satisfaction.

This Article proposes a mathematically expedient method of alleviating this tension. A four-moment capital asset pricing model captures the emotional impact of odd and even moments of statistical distributions. Critically, a four-moment CAPM transcends the limits of financial models that consider nothing beyond mean and variance in the distribution of returns. At an absolute minimum, four-moment CAPM gives mathematical voice to one of the key findings of prospect theory: the preference for skewed, lottery-like returns from actuarially unfavorable gambles.

Part I of this Article outlines the conventional capital asset pricing model. Part II describes prospect theory, perhaps the most celebrated expression of behavioral economics. To bridge the gap between the CAPM's neoclassical assumptions and prospect theory's behavioral observations, Part III specifies a four-moment capital asset pricing model based on a Taylor series expansion of logarithmic returns. Part IV examines instances of skewness preference across the landscape of financial economics. Part V pays close attention to pricing problems of initial public offerings as a special case.

\section{The Conventional CAPital Asset Pricing Model}

The conventional capital asset pricing model remains the dominant paradigm in financial risk management ${ }^{1}$ - at least among

1. See, e.g., Fischer Black, Capital Market Equilibrium with Restricted Borrowing, 45 J. Bus. 444, 444 (1972); Fischer Black, Michael C. Jensen \& Myron Scholes, The Capital Asset Pricing Model: Some Empirical Tests, in STUdIES IN THE THEORY of CAPITAL MARKETS 79 (Michael C. Jensen ed., 1972); John Lintner, Security Prices, Risk, and Maximal Gains from Diversification, 20 J. FIN. 587, 587 (1965); John Lintner, The Valuation of Risk Assets and the Selection of Risky Investments in Stock Portfolios and Capital Budgets, 47 REV. ECON. \& STAT. 13, 14 (1965); Jan Mossin, Equilibrium in a Capital Asset Market, 34 ECONOMETRICA 768, 769 (1966); William F. Sharpe, Capital Asset Prices: A Theory of Market Equilibrium Under Conditions of Risk, 19 J. Fin. 425, 427 (1964); Jack L. Treynor, Towards a Theory of Market Value of Risky Assets, in ASSET PRICING AND PORTFOLIO Performance: Models, Strategy and Performance Metrics 15 (Robert A. Korajczyk ed., 1999); Jack L. Treynor \& Fischer Black, Corporate Investment Decisions, in Modern Developments In Financial Management 310-27 (Stewart C. Myers ed., 1976). See generally Eugene F. Fama \& Kenneth R. French, The Capital Asset Pricing Model: Theory and Evidence, 18 J. ECON. PERSP. 25 (2004); BERNELL Kenneth Stone, Risk, Return, and Equilibrium: A General Single-Period THEORY OF AsSET SELECTION AND CAPITAL MARKET Equilibrium (1970). 
practitioners, if not among scholars. ${ }^{2}$ Once upon a time, long ago, "the hegemony of the CAPM" could be attributed "mostly to its apparent ease of applicability and, to a lesser extent, its empirical justification." ${ }^{3}$ The latter excuse, at least, has withered away. Despite evidence that beta is not positively related to returns on stock, ${ }^{4}$ much of contemporary financial theory still hinges on the CAPM. With resilience worthy "of cartoon characters like Wile E. Coyote who have the ability to come back to original shape after being blown to pieces," the CAPM persists "because (a) the empirical support for other asset-pricing models is no better, (b) the theory behind the CAPM has an intuitive appeal that other models lack, and (c) the economic importance of the empirical evidence against the CAPM ... is ambiguous." 5

"It takes a better theory to kill an existing theory," and the financial profession has "yet to see [a] better theory." Even Eugene Fama, beta's leading nemesis, has conceded that "market professionals (and academics) still think about risk in terms of market $\beta . "{ }^{\prime}$ Courts and other legal decision makers are even more committed to thinking of financial risk and asset pricing in terms of the conventional CAPM. ${ }^{8}$ In law and professional practice, if not in academic theory, the capital asset pricing model is alive and well. ${ }^{9}$

2. See Haim Levy, The Capital Asset Pricing Model in the 21st Century: Analytical, Empirical, and Behavioral Perspectives 4-5 (2012) (describing the CAPM and its constituent concepts, "particularly beta," as "probably the most widely employed financial measures used by academic researchers" and "even more intensively used by investment firms and practitioners").

3. Philip H. Dybvig \& Jonathan E. Ingersoll, Jr., Mean-Variance Theory in Complete Markets, 55 J. Bus. 233, 233 (1982).

4. See Eugene F. Fama \& Kenneth R. French, The Cross-Section of Expected Stock Returns, 47 J. FIN. 427, 428 (1992); see also Marc R. Reinganum, A New Empirical Perspective on the CAPM, 16 J. Fin. \& Quantitative Analysis 439, 439 (1981); Seha M. Tinic \& Richard R. West, Risk and Return: January vs. the Rest of the Year, 13 J. FIN. ECON. 561, 573 (1984).

5. Ravi Jagannathan \& Zhenyu Wang, The Conditional CAPM and the Cross-Section of Expected Returns, 51 J. FIN. 3, 4 (1996) (footnote omitted).

6. Tim Koller, Marc Goedhart \& David Wessels, Valuation: Measuring And Managing the Value of Companies 261 (5th ed. 2010).

7. Eugene F. Fama, Efficient Capital Markets: II, 46 J. FIN. 1575, 1593 (1991); accord Glenn N. Pettengill, Sridhar Sundaram \& Ike Mathur, The Conditional Relation Between Beta and Returns, 30 J. Fin. \& QuAntitATIVE ANALYSIS 101, 102 (1995).

8. See, e.g., In re Am. Classic Voyages Co., 367 B.R. 500, 513 n.19 (Bankr. D. Del. 2007) ("While there are other models to determine equity, CAPM is probably the most widely used." (quoting Peter V. Pantaleo \& Barry W. Ridings, Reorganization Value, 51 Bus. LAw. 419, 433 n.52 (1996))); cf. AEP Tex. N. Co. v. 
The CAPM expresses return on an asset as a function of risk, which in turn can be expressed as volatility, beta, or some other measure drawn from the second moment of the distribution of financial returns. ${ }^{10}$ The independent development, particularly by William Sharpe and John Lintner, of "general models represent[ing] equivalent approaches to the problem of capital asset pricing under uncertainty" gave rise to what we recognize today as the CAPM. ${ }^{11}$

The capital asset pricing model quantifies the premium demanded by the market for shouldering that asset's volatility over a benchmark represented by the return on a risk-free investment: ${ }^{12}$

$$
R_{a}=R_{f}+\beta_{a}\left(R_{m}-R_{f}\right)
$$

where $R_{a}, R_{m}$, and $R_{f}$ respectively represent returns on the asset, on the broader market of comparable investments, and on a risk-free investment, and where $\beta_{a}$ represents the individual asset's beta vis-àvis a portfolio based on the broader market. ${ }^{13}$ This formula takes the form of a linear equation where the return on an asset $\left(R_{a}\right)$ is expressed as a function of the premium over a risk-free baseline $\left(R_{m}-R_{f}\right){ }^{14}$

Within the capital asset pricing model, beta $\left(\beta_{a}\right)$ represents the slope of the linear function, and the risk-free return $\left(R_{f}\right)$ is a constant that defines the function's $y$-intercept. ${ }^{15}$ Modest algebraic rearrangement of the capital asset pricing model yields the following relationship:

Surface Transp. Bd., 609 F.3d 432, 443 (D.C. Cir. 2010) (observing that courts "do not sit as ... panel[s] of statisticians, but as ... panel[s] of generalist judges").

9. See Haim Levy, The CAPM Is Alive and Well: A Review and Synthesis, 16 Eur. Fin. MGMt. 43, 43 (2009); cf. LeVy, supra note 2, at 22 (describing the CAPM and related models of mean-variance optimization as "still 'alive and kicking"').

10. See Franco Modigliani \& Merton H. Miller, The Cost of Capital, Corporation Finance and the Theory of Investment, 48 AM. ECON. REV. 261, 262 (1958).

11. Eugene F. Fama, Risk, Return, and Equilibrium: Some Clarifying Comments, 23 J. FIN. 29, 40 (1968).

12. See Modigliani \& Miller, supra note 10, at 262.

13. See Robert A. Korajczyk, Introduction to ASSET PRICING AND Portfolio Performance: Models, Strategy and Performance Metrics, at xv (Robert A. Korajczyk ed., 1999).

14. See id.

15. See id. 


$$
R_{m}-R_{f}=\frac{R_{a}-R_{f}}{\beta_{a}}
$$

The left side of the foregoing equation represents the risk premium demanded for the entire asset class represented by a particular segment of the market. ${ }^{16}$ Modern portfolio theory expresses the risk premium as the difference between returns on a specific investment or class of investments and some sort of risk-free benchmark. ${ }^{17}$ This premium dictates a firm's cost of capital; indeed, capital asset pricing, in its original incarnation, offered a solution to the problem of determining the price that investors would demand for bearing risk in excess of a risk-free alternative. ${ }^{18}$

Another common application of the capital asset pricing model compares an index of equities designed to track the Standard and Poor's 500 against the putatively risk-free baseline of short-term Treasury bills. ${ }^{19}$ This market-wide risk premium is equivalent to the risk-adjusted premium expressed on the right side of the equationnamely, the risk premium for the asset vis-à-vis a risk-free investment, divided by the individual asset's beta. ${ }^{20}$

This ratio between risk-adjusted return and volatility bears closer examination. Recall that the foregoing equation is merely an algebraically reformulated version of the basic capital asset pricing model:

$$
R_{a}=R_{f}+\beta_{a}\left(R_{m}-R_{f}\right)
$$

The ratio of (1) the premium over a baseline return to (2) the volatility associated with that asset or portfolio demonstrates how market returns are adjusted for risk, or for some surrogate such as volatility or beta:

$$
\text { Treynor ratio }=\frac{R_{a}-R_{b}}{\beta_{a}}
$$

16. See id.

17. See Sharpe, supra note 1, at 426-27.

18. See Modigliani \& Miller, supra note 10, at 262.

19. See Handbook of Quantitative Finance And Risk Management 10 (Cheng-Few Lee, Alice C. Lee \& John Lee eds., 2010).

20. See Korajczyk, supra note 13, at xv. 
Algebraic manipulation, in one direction or another, connects the Treynor ratio of reward to volatility with the more general capital asset pricing model. Indeed, the Treynor ratio restates the capital asset pricing model. Although mathematical congruence undermines the contribution of the Treynor ratio to the testing of the capital asset pricing model as a scientific hypothesis, ${ }^{21}$ this definitional unity does make the Treynor ratio a convenient tool for evaluating and understanding the broader model of asset pricing. The Treynor ratio demonstrates that the general risk premium of a class of investments (such as the broader market of all publicly traded equities in the United States) is equivalent to the premium for a specific investment over risk-free return, discounted by the volatility of returns on that specific asset relative to returns on the benchmark class as a whole. ${ }^{22}$ In other words, we can extrapolate the Treynor ratio from the capital asset pricing model, and the capital asset pricing model from the Treynor ratio.

The Treynor ratio measures reward as return on an asset, $R_{a}$, above some benchmark return, $R_{b}$, relative to the volatility of that asset's return as expressed by its beta, $\beta_{a}{ }^{23}$ The benchmark return, $R_{b}$, often is, but need not be, equivalent to the risk-free baseline, $R_{f}$. The Treynor ratio closely resembles a generalized version of the Sharpe ratio of reward to variability (as measured by the standard deviation of portfolio returns): ${ }^{24}$

$$
\text { Generalized Sharpe ratio }=\frac{R_{a}-R_{b}}{\sigma}
$$

What unites the Sharpe and Treynor ratios is the evaluation of portfolio returns or portfolio manager performance according to the relationship between returns and some proxy for risk, whether volatility as measured through standard deviation or relative correlated volatility as measured through beta. ${ }^{25}$

21. See Richard Roll, A Critique of the Asset Pricing Theory's Tests, 4 J. FIN. ECON. 129, 130 (1977).

22. See Treynor, supra note 1 , at 17.

23. Id. at 16-17.

24. See William F. Sharpe, Mutual Fund Performance, 39 J. Bus. 119, 127 (1966); William F. Sharpe, Adjusting for Risk in Portfolio Performance Measurement, 1 J. Portfolio MGMT. 29, 30 (1975) [hereinafter Sharpe, Adjusting for Risk in Portfolio Performance Measurement].

25. See J.D. Jobson \& Bob M. Korkie, Performance Hypothesis Testing with the Sharpe and Treynor Measures, 36 J. FIN. 889, 891 (1981); Sharpe, Adjusting for Risk in Portfolio Performance Measurement, supra note 24, at 127. 


\section{PROSPECT THEORY}

The conventional CAPM rests upon a highly stylized theoretical foundation assuming perfectly rational economic agents. Law and other fields applying financial economics have struggled to account for behavioral departures from neoclassical assumptions of perfect rationality. Perhaps the most celebrated framework for explaining human decision-making under the influence of risk aversion and risk seeking is prospect theory. At a minimum, "prospect theory is . . . widely viewed as the best available description of how people evaluate risk in experimental settings." 26 Prospect theory has inspired a deeper body of work in behavioral economics. ${ }^{27}$

In their 1979 article that laid the initial foundations for prospect theory, Daniel Kahneman and Aaron Tversky identified varying conditions under which economic agents can be expected to behave in risk-averse or in risk-seeking ways. ${ }^{28}$ For example, in a "situation where winning is possible but not probable, most people choose the prospect that offers the larger gain." ${ }^{29}$ The possibility of a certain outcome within a mixed prospect renders certainty a special case of a broader "isolation effect," whereby the evaluation of distinct components of alternative choices can "produce inconsistent preferences." ${ }^{30}$ Moreover, upon examining not only "positive prospects," or "prospects that involve no losses," but also the impact of reversing "the signs of the outcomes ... so that gains are replaced by losses," Kahneman and Tversky also identified a "reflection effect." 31 The significance of the reflection effect lies in its implication "that risk aversion in the positive domain is accompanied by risk seeking in the negative domain." ${ }^{32}$

26. Nicholas C. Barberis, Thirty Years of Prospect Theory in Economics: A Review and Assessment, 27 J. ECON. PERSP. 173, 173 (2013).

27. See generally, e.g., DANiel Kahneman, Thinking, FAST AND Slow 27888 (2011); Peter P. Wakker, Prospect Theory: For Risk And Ambiguity (2010).

28. See Daniel Kahneman \& Amos Tversky, Prospect Theory: An Analysis of Decision Under Risk, 47 ECONOMETRICA 263, 263 (1979).

29. Id. at 267.

30. Id. at 271 .

31. Id. at 268 .

32. Id. (citing C. Arthur Williams, Jr., Attitudes Toward Speculative Risks as an Indicator of Attitudes Toward Pure Risk, 33 J. RisK \& INS. 577, 577-86 (1966); Peter C. Fishburn \& Gary A. Kochenberger, Two-Piece von Neumann-Morgenstern Utility Functions, 10 DeCISION SCI. 503, 503 (1979)). 
Combining the certainty effect with the reflection effect dramatically changes the nature of risk aversion. "In the positive domain, the certainty effect contributes to a risk averse preference for a sure gain over a larger gain that is merely probable." ${ }^{33}$ By contrast, "[i]n the negative domain," the certainty effect "leads to a risk seeking preference for a loss that is merely probable over a smaller loss that is certain." ${ }^{34}$ Because "the reflection effect eliminates aversion for uncertainty or variability" for losses, the "same psychological principle - the overweighting of certaintyfavors risk aversion in the domain of gains and risk seeking in the domain of losses." 35 In other words, "certainty increases the aversiveness of losses as well as the desirability of gains." ${ }^{36}$

Prospect theory's value function calculates utility according to "gains and losses rather than ... final asset positions." ${ }^{37}$ Noting "the presence of risk seeking in preferences among positive as well as among negative prospects," Harry Markowitz had "proposed a utility function which has convex and concave regions in both the positive and the negative domains." ${ }^{\prime 3}$ Prospect theory accordingly adopts a "value function" that is "concave for gains and . . . convex for losses." ${ }^{39}$ Moreover, prospect theory treats "changes of wealth, rather than final asset positions that include current wealth," as the true "carriers of value or utility." 40 "This conclusion," a repudiation of expected utility theory, represents "the cornerstone" of prospect theory as "an alternative theory of risky choice."

Treating "changes in wealth or welfare, rather than final states," as "carriers of value" harmonizes prospect theory "with basic principles of perception and judgment." 42 Human responses "to attributes such as brightness, loudness, or temperature" account for "the past and present context of experience." ${ }^{43}$ As with physical stimuli, so with "non-sensory attributes such as health, prestige, and wealth." "Many sensory and perceptual dimensions share the

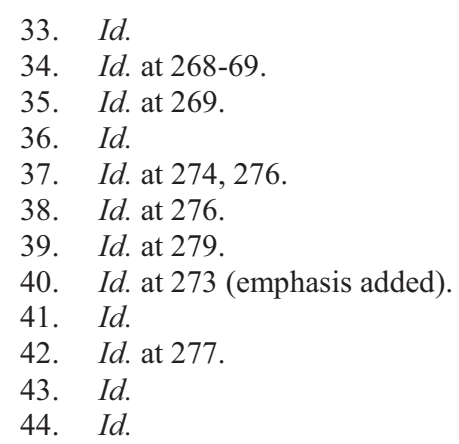


property that the psychological response is a concave function of the magnitude of physical change." ${ }^{45}$ Again, by analogy to physical perception: "[I]t is easier to discriminate between a change of $3^{\circ}$ and a change of $6^{\circ}$ in room temperature, than it is to discriminate between a change of $13^{\circ}$ and a change of $16^{\circ} .{ }^{\prime 46}$ In principle, the same change in sensitivity applies "to the evaluation of monetary changes. ${ }^{47}$

Kahneman and Tversky's own summary of prospect theory's value function thus identifies three distinctive properties. The value function is:

(i) defined on deviations from the reference point;

(ii) generally concave for gains and commonly convex for losses; and

(iii) steeper for losses than for gains. ${ }^{48}$

Stripped of its nuances, "prospect theory predicts that people generally make risk-averse decisions when choosing between options that appear to be gains and risk-seeking decisions when choosing between options that appear to be losses." ${ }^{49}$ Especially as expanded by Tversky and Kahneman's 1992 paper outlining a "cumulative" modification of their approach, ${ }^{50}$ prospect theory makes behavioral predictions arising from three basic features of human beings' core cognitive system. ${ }^{51}$

First, all decision-making takes place relative to a neutral reference point, or "aspiration level." ${ }^{2}$ Outcomes exceeding this reference point are gains. Outcomes below the reference point are losses. "Risk is the prospect of not meeting the target rate of return

45. Id. at 278 .

46. Id.

47. Id.

48. Id. at 279 .

49. Chris Guthrie, Prospect Theory, Risk Preference, and the Law, $97 \mathrm{Nw.}$ U. L. REV. 1115, 1116 (2003).

50. Amos Tversky \& Daniel Kahneman, Advances in Prospect Theory: Cumulative Representation of Uncertainty, 5 J. RISK \& UNCERTAINTY 297, 299 (1992).

51. See KAHNEMAN, supra note 27, at 282.

52. See John W. Payne, Dan J. Laughhunn \& Roy Crum, Translation of Gambles and Aspiration Level Effects in Risky Choice Behavior, 26 MgMT. SCI. 1039, 1039 (1980); John W. Payne, Dan J. Laughhunn \& Roy Crum, Further Tests of Aspiration Level Effects in Risky Choice Behavior, 27 MGMT. ScI. 953, 953 (1981).

53. See Peter C. Fishburn, Mean-Risk Analysis with Risk Associated with Below- Target Returns, 67 Am. ECON. ReV. 116, 116-26 (1977). 
... [i]f you are one hundred percent sure of making the target return, then it is a zero risk proposition." ${ }^{54}$

Second, loss aversion means that losses, when directly weighted or compared against gains, loom larger. ${ }^{55}$ This is one respect in which prospect theory preserves the premises of expected utility theory. Prospect theory assumes that most individuals, as an expression of innate risk aversion, fear potential losses more than they covet potential gains. ${ }^{56}$ Within a formal economic framework, "loss aversion" eliminates the neutrality of "the dynamic aggregation rules people follow." ${ }^{57}$ The Supreme Court of the United States long ago rendered this sentiment in more straightforward terms: "Threat of loss, not hope of gain, is the essence of economic coercion." 58 Even more plainly, "[l]osing hurts worse than winning feels good." 59

Third and finally, diminishing sensitivity applies to upward and downward perceptions and to evaluation of changes of wealth. ${ }^{60} \mathrm{In}$ concert, these three principles - neutral reference point, loss aversion, and diminishing sensitivity - can be illustrated through a graph showing an asymmetrical sigmoid curve whose inflection point occurs at the neutral adaptation level, whose steeper slope below the adaptation level demonstrates loss aversion, and whose declining rate of change in both directions reflects diminishing sensitivity to gains and to losses. ${ }^{61}$ Exploiting the mathematical properties of well-behaved cumulative distribution functions (which after all "are positive, have positive first derivatives - the probability densities - and if they are unimodal, have negative second derivatives beyond the mode") generates a value function that satisfies these conditions. ${ }^{62}$

54. James C.T. Mao, Survey of Capital Budgeting: Theory and Practice, 25 J. Fin. 349, 353 (1970); see also Robert Libby \& Peter C. Fishburn, Behavioral Models of Risk Taking in Business Decisions: A Survey and Evaluation, 15 J. ACCT. RES. 272, 288-89 (1977).

55. See KAHNEMAN, supra note 27, at 282.

56. Id.

57. See Shlomo Benartzi \& Richard H. Thaler, Myopic Loss Aversion and the Equity Premium Puzzle, 110 Q.J. Economics 73, 74 (1995).

58. United States v. Butler, 297 U.S. 1, 81 (1936) (Stone, J., dissenting).

59. Lewis GrizZard, GetTIN' It On: A Down-Home Treasury 72 (1989); accord Joe GARAgIOLA, IT's ANYBODY's BALLGAME 108-09 (1988). Lewis Grizzard (1946-94) was a humor columnist for the Atlanta Journal-Constitution.

60. See KAHNEMAN, supra note 27, at 282.

61. See Kahneman \& Tversky, supra note 28, at 282-83.

62. Denis Conniffe, The Generalised Extreme Value Distribution as Utility Function, 38 Econ. \& Soc. Rev. 275, 275 (2007); see also Marco LiCalzi \& Annamaria Sorato, The Pearson System of Utility Functions, 172 EuR. J. 
Without loss of generality, we can illustrate prospect theory's value function through a transformation of the cumulative distribution function of a lognormal distribution with parameters $\mu=0$ and $\sigma=\sqrt{ } 3 / 5$ :

$$
\begin{aligned}
& F(\ln x ; \mu, \sigma)=\operatorname{erf}\left\lfloor\frac{\ln (x+1)-\mu}{\sigma \sqrt{2}}\right\rfloor \\
& F\left(\ln x ; \mu=0, \sigma=\frac{\sqrt{3}}{5}\right)=\operatorname{erf}\left[\frac{5 \ln (x+1)}{\sqrt{6}}\right]
\end{aligned}
$$

A plot of that function alongside $F(x ; \alpha=1, \beta=5)=\frac{2 \cdot(x+1)^{5}}{1+(x+1)^{5}}-1$, the corresponding cumulative distribution function of the log-logistic distribution, ultimately looks like this: ${ }^{63}$

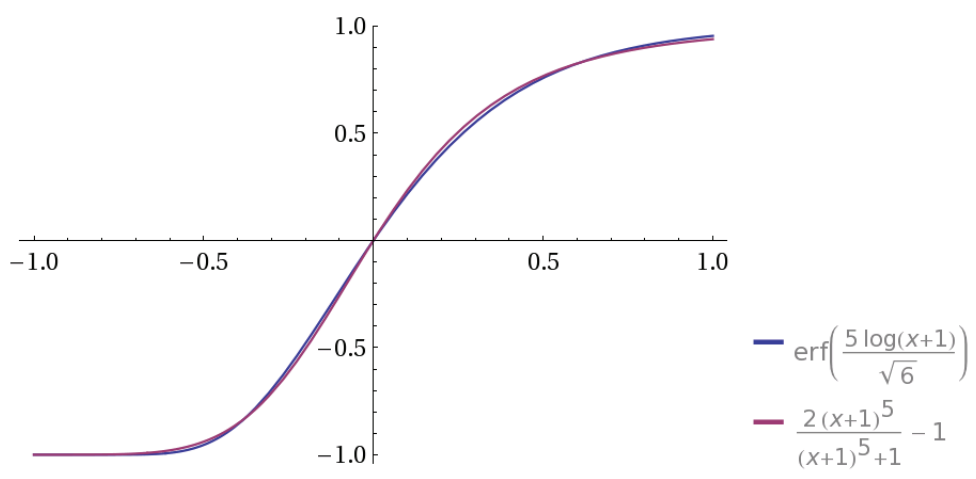

"If prospect theory had a flag, this image would be drawn on it." ${ }^{\circ 4}$

Operational Res. 560, 560-73 (2006); James Ming Chen, Flagging Prospect Theory 1 (Feb. 13, 2009) (unpublished method paper), http://ssrn.com/abstract= 2216916 [https://perma.cc/PE3U-7723].

63. I entered the following command in Wolfram Alpha: plot $\operatorname{erf}\left(5^{*} \ln (\mathrm{x}+1) / \operatorname{sqrt}(6)\right)$ and $2 *(\mathrm{x}+1)^{\wedge} 5 /\left(1+(\mathrm{x}+1)^{\wedge} 5\right)-1$ for $-1<\mathrm{x}<1$.

64. KahNEMAN, supra note 27, at 282. 


\section{A Four-MOMENT CAPITAL ASSET PRICING MODEL}

Mathematical analysis provides a way to harmonize the conventional capital asset pricing model with behavioral economics. Overtly behavioral interpretations of moment-based theories of finance associate different moments with different emotions. ${ }^{65}$ Law and other fields of applied behavioral science require financial models whose primary or even exclusive purpose is to describe economic behavior as undertaken by actual humans, as opposed to hypothetical economic reason dictated by quantitative logic.

Prospect theory, in particular, reflects "the psychophysics of chances." Although "[p]sychophysical theories and moments theories are theories of Everyman because they are based mechanistically on principles" that are presumed to bind all of humanity, ${ }^{67}$ mathematical specification of behavioral theories of Everyman represents a first step toward richer accounts of the full range of considerations, rational and emotional, that affect human decisions.

We can reduce the conceptual distance separating the conventional capital asset pricing model from behavioral economics by adopting a four-moment variant of the CAPM. If mean-variance optimization arises "from the idea that the investor prefers higher expected returns and lower risk," then higher-moment CAPM presumes, "ceteris paribus, investors prefer a high probability of an extreme event in the positive direction over a high probability of an extreme event in the negative direction." ${ }^{98}$ On that assumption, mean-variance optimization under the conventional CAPM represents merely a special case of a more comprehensive model that accounts for asymmetry in returns (as expressed by skewness) and the relative probability of extreme events in the distribution of

65. See, e.g., Ole Hagen, Separation of Cardinal Utility and Specific Utility of Risk in Theory of Choices Under Uncertainty, 3 SAERTRYKK AV STATSøKONOMISK TIDSSKRIFT 81 (1969).

66. Daniel Kahneman \& Amos Tversky, Choices, Values, and Frames, 39 AM. PSYCHOL. 341, 344 (1984).

67. Lola L. Lopes, Between Hope and Fear: The Psychology of Risk, 20 AdVANCES EXPERIMENTAL SOC. PSYCHOL. 255, 283 (1987).

68. Campbell R. Harvey et al., Portfolio Selection with Higher Moments, 10 Quantitative Fin. 469, 471 (2010); Gustavo M. de Athayde \& Renato G. Flôres Jr., Finding a Maximum Skewness Portfolio-A General Solution to Three-Moments Portfolio Choice, 28 J. ECON. DynAmics \& CONTROL 1335, 1342 (2004). 
returns (as expressed by kurtosis). ${ }^{69}$ The goal, therefore, is to devise a theoretically coherent account of investor preferences with respect to no fewer than the first four moments-mean, variance, skewness, and kurtosis.

One mathematically cogent "way of dealing with higher moments in the asset allocation is the use of the Taylor series expansion to derive an approximation of the expected utility function." " A higher-order Taylor series expansion can "simplify[] the asset allocation task" the presence of . . . higher order moments and parameter uncertainty." 72 Specifically, to "measur[e] the effect of higher moments on ... asset allocation," we can "approximate the expected utility by a Taylor series expansion around the expected wealth." 73

The Taylor series expansion for a function, $f(x)$, that is infinitely differentiable at value $a$ takes the form of a power series: ${ }^{74}$

$$
f(x)=f(a)+\frac{f^{\prime}(a)}{1 !}(x-a)+\frac{f^{\prime \prime}(a)}{2 !}(x-a)^{2}+\frac{f^{\prime \prime}(a)}{3 !}(x-a)^{3}+\ldots
$$

Exploiting multiple mathematical identities-namely, that $(x-a)^{0}$ and 0 ! both equal 1 , and the zeroth order derivative of $f(x)$ is $f(x)$ itself-enables us to express the Taylor series expansion in a more compact form:

$$
f(x)=\sum_{n=0}^{\infty} \frac{f^{(n)}(a)}{n !}(x-a)^{n}
$$

Accordingly, if an investor's "utility function is expressed in terms of the wealth distribution, so that":

69. See Eric Jondeau \& Michael Rockinger, Optimal Portfolio Allocation Under Higher Moments, 12 Eur. Fin. MGMt. 29, 33 (2006).

70. Id. at 30 .

71. Harvey et al., supra note 68 , at 470 .

72. Id. at 469 .

73. Jondeau \& Rockinger, supra note 69 , at 33.

74. See Taylor Series, WIKIPEDIA, https://en.wikipedia.org/wiki/Taylor_series [https://perma.cc/2VKF-S8XT] (last visited Apr. 12, 2016). Unless otherwise noted, background information on the mathematics of the Taylor series expansion comes from this source. The special case of a Taylor series where $a=0$ is often designated a Maclaurin series. 


$$
\langle U(w)\rangle=\int U(w) f(w) d w
$$

"where $f(w)$ is the probability distribution function of end-of-period wealth, that depends on the multivariate distribution of returns" and the weights of the portfolio's components, then "the infinite-order Taylor series expansion of the utility function is":

$$
U(w)=\sum_{n=0}^{\infty} \frac{U^{(n)}(\bar{w})(w-\bar{w})^{n}}{n !}
$$

where $\bar{w}=\rangle w\left\langle=1+\alpha^{\prime} \mu\right.$ designates the expected end-of-period wealth, $\mu$ designates the vector of expected returns, and $\alpha$ designates the vector of portfolio weights. ${ }^{75}$

The application of this model to a simple set of financial returns is even more straightforward. "Let $R$ and $r$ denote simple (arithmetic) and logarithmic (continuously compounded) returns respectively $\ldots .{ }^{976}$ By definition, $r_{t}=\ln \left(1+R_{t}\right),{ }^{77}$ where $r_{t}$ designates the "continuously compounded return or log return . . of an asset" and "is defined to be the natural logarithm of [the asset's] gross return $\left(1+R_{t}\right) .{ }^{.78}$ It is important to express returns in logarithmic form and calculate geometric rather than arithmetic average returns. "When returns are serially correlated, then the arithmetic average can lead to misleading estimates .... ."79 Arithmetic average return exceeds its geometric counterpart; "if the returns are log-normally distributed, the difference between the two is one-half the variance of the returns." ${ }^{80}$ The computation of log returns not only overcomes "[t]he difficulty of manipulating geometric averages" but also allows the expression of "continuously compounded multiperiod return [as] simply the sum of continuously compounded single-period returns": ${ }^{\prime 1}$

75. See Jondeau \& Rockinger, supra note 69 , at 33.

76. Javier Estrada, Mean-Semivariance Behaviour: An Alternative Behavioural Model, 3 J. EmERging MKt. FIN. 231, 241 (2004).

77. See id.

78. John Y. Campbell, Andrew W. Lo \& A. Craig MacKinlay, The ECONOMETRICS OF FINANCIAL MARKETS 11 (1997).

79. Rajnish Mehra \& Edward C. Prescott, The Equity Premium in Retrospect, in HandBooK of THE Economics of Finance 890, 892 (George M. Constantinides, Milton Harris \& René M. Stulz eds., 2003).

80. Id. at 891.

81. CAMPBELL, Lo \& MACKINLAY, supra note 78, at 11. 


$$
\begin{aligned}
& r_{t}(k)=\ln \left[1+R_{t}(k)\right]=\ln \left[\left(1+R_{t}\right) \cdot\left(1+R_{t-1}\right) \cdots\left(1+R_{t-k+1}\right)\right] \\
& r_{t}(k)=\ln \left(1+R_{t}\right)+\ln \left(1+R_{t-1}\right)+\cdots+\ln \left(1+R_{t-k+1}\right) \\
& r_{t}(k)=r_{t}+r_{t-1}+\cdots+r_{t-k+1}
\end{aligned}
$$

Even more importantly, this expression of log returns lends itself to a very simple and elegant Taylor series expansion. For the logarithmic function $\ln (1+x)$, the Taylor series expansion takes this form: ${ }^{82}$

$$
\ln (1+x)=\sum_{n=1}^{\infty}(-1)^{n+1} \frac{x^{n}}{n}
$$

Generalizing the Taylor series expansion to account for $\ln (1+x)$ at $x=\mu$ yields:

$$
\ln (1+\mu)+\frac{x-\mu}{1+\mu}-\frac{(x-\mu)^{2}}{2(1+\mu)^{2}}+\frac{(x-\mu)^{3}}{3(1+\mu)^{3}}-\frac{(x-\mu)^{4}}{4(1+\mu)^{4}}+o\left[(x-\mu)^{5}\right]
$$

where $o\left[(x-\mu)^{5}\right]$ represents remaining terms of the fifth order and above. ${ }^{83}$ Inasmuch as time series also rely on logarithmic returns, a more elaborate third-order (or higher) Taylor series expansion may be derived by "relat[ing] the discount factor to the marginal rate of substitution between periods $t$ and $t+1$, in a two-period economy." ${ }^{84}$

Somewhat optimistically, Javier Estrada leaps directly from this model to a Taylor series expansion that consists exclusively of alternative central statistical moments. He is partially correct-and almost entirely correct if we modify the definition of skewness and kurtosis. If we "let $\mu$ and $\sigma^{2}$ [represent] the mean and variance of $R$," then the conventional CAPM takes the form of a Taylor series expansion of expected returns: $:^{85}$

82. See Taylor Series, WIKIPEDIA, supra note 74.

83. See Taylor Series for $\ln (1+x)$ at $x=y$, WolframAlpha, http://www.wolframalpha.com/input/?i=taylor+series + for $+\ln \% 281 \% 2 \mathrm{Bx} \% 29+$ at $+\mathrm{x}$ \%3Dy [https://perma.cc/67QM-WQLW] (last visited Apr. 12, 2016).

84. Campbell R. Harvey \& Akhtar Siddique, Conditional Skewness in Asset Pricing Tests, 55 J. FIN. 1263, 1269 (2000).

85. Estrada, supra note 76, at 241. 


$$
\langle r\rangle=\langle\ln (1+R)\rangle \approx \ln (1+\mu)+\frac{x-\mu}{1+\mu}-\frac{1}{2} \cdot \frac{\sigma^{2}}{(1+\mu)^{2}}+R_{2}[\ln (1+R)]
$$

where $R_{n}(x)$ designates the remaining terms of the Taylor series expansion beyond order $n$ (which in this example is 2). ${ }^{86}$ Estrada omits the second term of the series, $\frac{x-\mu}{1+\mu}$, and takes no explicit account of the Taylor remainder.

More explicitly, Estrada proposes to interpret the remainder term as direct implementations of skewness and kurtosis: ${ }^{87}$

$$
\langle r\rangle=\langle\ln (1+R)\rangle \approx \ln (1+\mu)-\frac{1}{2} \cdot \frac{\sigma^{2}}{(1+\mu)^{2}}+\frac{1}{3} \cdot \frac{\text { Skew }}{(1+\mu)^{3}}-\frac{1}{4} \cdot \frac{\text { Kurt }}{(1+\mu)^{4}}
$$

And, likewise, for "[a]n approximate expected utility based on mean, variance, skewness and kurtosis ... [for] an investor [who] displays a logarithmic . . . utility function": 88

$$
\langle r\rangle=\langle\ln (1+R)\rangle \approx \ln (1+\mu)-\frac{1}{2} \cdot \frac{\sigma^{2}}{(1+\mu)^{2}}+\frac{1}{3} \cdot \frac{\text { Skew }}{(1+\mu)^{3}}-\frac{1}{4} \cdot \frac{\text { Kurt }}{(1+\mu)^{4}}
$$

Estrada's interpretation of this Taylor series expansion is correct, but only if one defines skewness and kurtosis, respectively, as the third and fourth central moments rather than the third and fourth standardized moments. Potential confusion arises from other sources' adoption of the definition of skewness as the third standardized moment, $\gamma_{1}=\left\langle\left(\frac{x-\mu}{\sigma}\right)^{3}\right\rangle=\frac{\mu_{3}}{\sigma^{3}} .89$ Note further that standard treatments of kurtosis subtract three from the fourth standardized moment in order to express excess kurtosis by reference

86. See Taylor's Theorem, WIKIPEDIA, https://en.wikipedia.org/wiki/Taylor\% 27s_theorem [https://perma.cc/AVQ3-CL2W] (last visited Apr. 12, 2016).

87. Estrada, supra note 76, at 241.

88. Id. at 246.

89. See, e.g., Leslie A. Balzer, Investment Risk: A Unified Approach to Upside and Downside Returns, in MANAgING Downside RISK IN FInANCIAL Markets: Theory, Practice And IMPlementation 103, 121 (Frank A. Sortino \& Stephen E. Satchell eds., 2001). 
to the kurtosis of a normal Gaussian distribution: $\gamma_{2}=\beta_{2}-3=\frac{\mu_{4}}{\sigma^{4}}-3$.

In the interest of precision, we should restate Estrada's interpretation of the Taylor series expansion of log returns:

$$
\begin{aligned}
& \ln (1+x) \text { at }(x=\mu) \\
& \approx \ln (1+\mu)+\frac{x-\mu}{1+\mu}-\frac{(x-\mu)^{2}}{2(1+\mu)^{2}}+\frac{(x-\mu)^{3}}{3(1+\mu)^{3}}-\frac{(x-\mu)^{4}}{4(1+\mu)^{4}}+o\left[(x-\mu)^{5}\right] \\
& \approx \ln (1+\mu)+\frac{x-\mu}{1+\mu}-\frac{\sigma^{2}}{2(1+\mu)^{2}}+\frac{\mu_{3}}{3(1+\mu)^{3}}-\frac{\mu_{4}}{4(1+\mu)^{4}}+o\left(\mu_{5}\right)
\end{aligned}
$$

Therefore, this Taylor series expansion does correspond to definitions for skewness and kurtosis, ${ }^{90}$ but only if we define "skewness and kurtosis ... as central higher moments" in place of these terms' traditional "statistical definitions as standardised central higher moments." 91

If we insist, very modest rearrangement allows us to restate the Taylor series expansion in terms of more traditional interpretations of skewness and kurtosis - namely, $\gamma_{1}, \beta_{2}$, and $\gamma_{2}$ :

$$
\begin{aligned}
& \ln (1+x) \text { at }(x=\mu) \\
& \approx \ln (1+\mu)+\frac{x-\mu}{1+\mu}-\frac{\sigma^{2}}{2(1+\mu)^{2}}+\frac{\gamma_{1} \sigma^{3}}{3(1+\mu)^{3}}-\frac{\beta_{2} \sigma^{4}}{4(1+\mu)^{4}}+o\left(\mu_{5}\right) \\
& \approx \ln (1+\mu)+\frac{x-\mu}{1+\mu}-\frac{\sigma^{2}}{2(1+\mu)^{2}}+\frac{\gamma_{1} \sigma^{3}}{3(1+\mu)^{3}}-\frac{\left(\gamma_{2}+3\right) \sigma^{4}}{4(1+\mu)^{4}}+o\left(\mu_{5}\right)
\end{aligned}
$$

The advantage of defining skewness and kurtosis in this Taylor series expansion as central moments, however, is the clarity with which the expression,

$$
\ln (1+\mu)+\frac{x-\mu}{1+\mu}-\frac{\sigma^{2}}{2(1+\mu)^{2}}+\frac{\mu_{3}}{3(1+\mu)^{3}}-\frac{\mu_{4}}{4(1+\mu)^{4}}+o\left(\mu_{5}\right),
$$

90. Cf. Jondeau \& Rockinger, supra note 69, at 34 (adopting a functionally equivalent definition of the Taylor series expansion of expected returns).

91. Id. at 34 n.5. 
demonstrates that the investor's "expected utility depends on all central moments of the distribution of the end-of-period wealth." ${ }^{92}$

Of even greater significance is what the Taylor series expansion implicitly says about the impact of skewness and kurtosis on investor welfare. Under rather modest assumptions- "positive marginal utility, decreasing absolute risk aversion at all wealth levels," and a "strict consistency" in the investor's attitude toward a given statistical moment without regard to her or his wealth-"the following inequalities hold": ${ }^{3}$

$$
\begin{aligned}
& U^{(n)}(w)>0 \forall w, \text { if } n \text { is odd and } \\
& U^{(n)}(w)<0 \forall w, \text { if } n \text { is even. }
\end{aligned}
$$

Specifically, investors "have positive preference for positive skewness" and "negative preference for negative skewness." 94 The Taylor series expansion of any utility function shows "that if the third derivative of the utility function is positive, there is a preference for skewness." commonly employed in economics and finance reveal a positive third derivative." 96

Combining what we already know about variance-that investors dislike it, at least on the downside - with this preference for positive skewness enables us to generalize to the next moment, kurtosis: "Consistent risk aversion, strict consistency of moment preference and positive preference for positive skewness imply negative preference for the fourth statistical moment (kurtosis). ${ }^{997}$ Or

92. Id. at 33 .

93. Id. at 34 .

94. Robert C. Scott \& Philip A. Horvath, On the Direction of Preference for Moments of Higher Order Than the Variance, 35 J. FIN. 915, 917 (1980); see also Markus K. Brunnermeier, Christian Gollier \& Jonathan A. Parker, Optimal Beliefs, Asset Prices, and the Preference for Skewed Returns, 97 Am. ECON. REV. 159, 164 (2007).

95. LEVY, supra note 2, at 61 n.4.

96. Id.; see also id. at 70-71 (suggesting that decreasing absolute risk aversion "implies that investors like skewness" and deducing from this premise that the prevalence of a positive third derivative in "the most commonly employed preferences" compels close attention to that derivative). "Skewness preferences and positive third derivatives are related to third degree Stochastic Dominance." Id. at 61 n.4. See generally G.A. Whitemore, Third-Degree Stochastic Dominance, 60 AM. ECON. REV. 457 (1970).

97. Scott \& Horvath, supra note 94, at 917-18. 
in even simpler terms: "[I]nvestors like mean return and positive skewness and dislike variance and kurtosis." 98 The odd moments, mean and skewness, advance returns, while the even moments "produce a drag on expected compound return." 99 The alternating treatment of odd- and even-numbered mathematical moments represents a logical extension of "an essential non-linear feature of observed investor behaviour" already "capture[d]" by the singlesided treatment of semivariance: "[M]ost investors perceive infrequent large losses or shortfalls [to be] far more risky than more frequent smaller losses or shortfalls." 100

The adage that investors generally "prefer high values for odd moments and low ones for even moments" reaches its greatest clarity in the extremes of the distribution. ${ }^{101}$ Odd moments "can be seen as a way to decrease extreme values on the side of losses and increase them on the gains"."102 Over the long haul, positive skewness indicates the presence of outsized gains; it suggests the tantalizing possibility that certain holdings in the portfolio will offer disproportionately large payouts, as though they were winning lottery tickets. ${ }^{103}$ By contrast, "even moments measure dispersion, and therefore volatility; something undesirable, that increases the uncertainty of returns." 104

Combining this insight with the basic, general definition of the Taylor series expansion as a function of differentials, factorials, and polynomials,

$$
f(x)=f(a)+\frac{f^{\prime}(a)}{1 !}(x-a)+\frac{f^{\prime \prime}(a)}{2 !}(x-a)^{2}+\frac{f^{\prime \prime}(a)}{3 !}(x-a)^{3}+\ldots,
$$

enables an even simpler approximation of expected returns or investor utility as a "preference function": 105

98. Estrada, supra note 76, at 241.

99. Id.

100. Balzer, supra note 89 , at 130.

101. Athayde \& Flôres, supra note 68, at 1336.

102. Id.

103. See Turan G. Bali, Nusret Cakici \& Robert F. Whitelaw, Maxing Out: Stocks as Lotteries and the Cross-Section of Expected Returns, 99 J. FIN. ECON. 427, 444 (2011).

104. Athayde \& Flôres, supra note 68, at 1336.

105. Jondeau \& Rockinger, supra note 69 , at 35. 


$$
\langle U(w)\rangle \approx U(\bar{w})+\frac{1}{2 !} U^{(2)}(\bar{w}) \sigma^{2}+\frac{1}{3 !} U^{(3)}(\bar{w}) s^{3}+\frac{1}{4 !} U^{(4)}(\bar{w}) k^{4}
$$

where $s$ and $k$ designate skewness and kurtosis, again defined as central moments. Consistent with our understanding of investor responses to odd and even moments, the actual expected utility approximated by this function "depends positively on expected return and skewness and negatively on variance and kurtosis." ${ }^{106}$ In this view of the approximate preference function, the work of sorting expected return and skewness from variance and kurtosis is performed by the sign of the odd- and even-numbered derivatives of the utility function.

\section{SKEWNESS PREFERENCE AND THE LONGING FOR LOTTERIES}

Prospect theory illuminates multiple problems in behavioral finance. In economics generally and in finance in particular, the real challenge lies in "know[ing] exactly how to apply" prospect theory's "many remarkable insights." 107 One of the most useful applications of prospect theory begins with an examination of the cluster of preferences aptly predicted by the lottery effect within prospect theory's fourfold pattern. It has long been known that many investors fail to diversify their portfolios. Many investors hold just a few stocks, or even just one. ${ }^{108}$ The failure to diversify - perhaps more persuasively characterized as the tendency to concentrate holdings within a portfolio - is the true manifestation of optimism and risk seeking. Individual investors, whether optimistic or realistic, tend to allocate similar amounts to equity, relative to safer asset classes such as bonds or cash. ${ }^{109}$ The difference is that optimists eschew diversification to their detriment. ${ }^{110}$

Optimism does appear to have positive effects on entrepreneurship, self-employment, and raw pleasure in one's

106. Id.

107. Barberis, supra note 26, at 173-74.

108. See Ronald C. Lease, Wilbur G. Lewellen \& Gary G. Schlarbaum, The Individual Investor: Attributes and Attitudes, 29 J. Fin. 413, 425 (1974). See generally Wilbur G. Lewellen, Ronald C. Lease \& Gary G. Schlarbaum, Patterns of Investment Strategy and Behavior Among Individual Investors, 50 J. Bus. 296, 315 (1977).

109. See Meir Statman, The Diversification Puzzle, 60:4 Fin. AnAlysts J. 44, 50 (July/Aug. 2004).

110. Id. at 45 . 
work. ${ }^{111}$ But its impact on financial prudence is decidedly mixed at best, and arguably quite deleterious to those investors who are unfortunate enough to be more confident and optimistic than their counterparts. (Gentlemen: I'm speaking to you. ${ }^{112}$ The greater an investor's distance from women, the worse the results from trading: "Single men traded less sensibly than married men, and married men traded less sensibly than single women: the less the female presence, the less rational the approach to trading in the markets."113) Optimism may also be highlighted by its contrast with its emotional opposite: the outsized fear of dying right after buying an annuity, which suppresses demand for an otherwise useful financial tool for retirement planning. ${ }^{114}$

The mathematical expression of a sunny outlook is a preference for skewness. Positive skewness suggests the possibility that certain holdings in the portfolio will offer disproportionately large payouts, as though they were winning lottery tickets. ${ }^{115}$ On average, stocks perceived to be positively skewed will earn lower returns. ${ }^{116}$

This preference for "positively skewed, or lottery-like, wealth distributions" may be expressed by adjusting the shape parameters of cumulative prospect theory's weighting functions. ${ }^{117}$ By shifting Tversky and Kahneman's original gain and loss weighting parameters, respectively, from $\gamma \approx 0.61$ and $\delta \approx 0.69^{118}$ to $\gamma \approx 0.4$ and $\delta \approx 0.65$, we can observe an even more pronounced "overweighting of low probabilities" in the domain of gains (which is again depicted in blue, relative to red for the domain of losses and gold for perfect risk neutrality): ${ }^{19}$

111. See Manju Puri \& David T. Robinson, Optimism and Economic Choice, 86 J. Fin. ECON. 71, 86 (2007).

112. See Brad M. Barber \& Terrance Odean, Boys Will Be Boys: Gender, Overconfidence, and Common Stock Investment, 116 Q.J. ECON. 261, 289 (2001).

113. Michael Lewis, Boomerang: Travels in the New Third World 37 (2011).

114. See Wei-Yin Hu \& Jason S. Scott, Behavioral Obstacles in the Annuity Market, 63:6 Fin. ANALYSTS J. 71, 79 (Nov./Dec. 2007).

115. See Bali, Cakici \& Whitelaw, supra note 103, at 428; Nicholas Barberis \& Ming Huang, Stocks as Lotteries: The Implications of Probability Weighting for Security Prices, 98 AM. ECON. REV. 2066, 2080-82 (2008).

116. See Brian Boyer, Todd Mitton \& Keith Vorkink, Expected Idiosyncratic Skewness, 23 REV. FIN. STUD. 169, 171 (2010).

117. Barberis \& Huang, supra note 115, at 2071.

118. Cf. Tversky \& Kahneman, supra note 50, at 311-12.

119. Barberis \& Huang, supra note 115, at 2071. The following image was generated at WOLFRAMALPHA, http://www.wolframalpha.com/input/? $\mathrm{i}=\mathrm{plot}+\mathrm{x} \%$ $5 \mathrm{E} .4 \% 2 \mathrm{~F} \% 28 \mathrm{x} \% 5 \mathrm{E} .4 \% 2 \mathrm{~B} \% 281 \mathrm{x} \% 29 \% 5 \mathrm{E} .4 \% 29 \% 5 \mathrm{E} \% 281 \% 2 \mathrm{~F} .4 \% 29+$ and $+\mathrm{x} \% 5 \mathrm{E}$. 


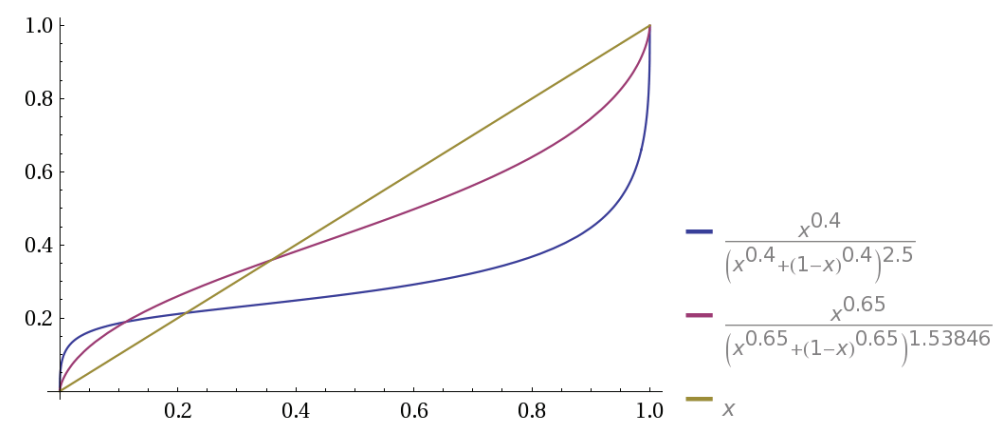

The relationship between low returns, positive skewness, and investor affinity toward investments offering lottery-like payoffs appears across a wide variety of financial settings.

\section{A. Prize-Linked Savings Accounts}

Americans spent $\$ 70.2$ billion on lottery tickets in fiscal year $2014 .{ }^{120}$ That amount, confined to the forty-four states and the District of Columbia where lotteries are legal, exceeds the amount spent in all fifty states "on sports tickets, books, video games, movie tickets, and recorded music sales." 121 Of the $\$ 70.2$ billion in lottery sales, $\$ 19.9$ billion was remitted to lottery-sponsoring jurisdictions as revenue. ${ }^{122}$ The profoundly negative economic impact of the lottery falls disproportionately on the poor, ${ }^{123}$ many of whom treat

$65 \% 2 \mathrm{~F} \% 28 \mathrm{x} \% 5 \mathrm{E} .65 \% 2 \mathrm{~B} \% 281 \mathrm{x} \% 29 \% 5 \mathrm{E} .65 \% 29 \% 5 \mathrm{E} \% 281 \% 2 \mathrm{~F} .65 \% 29+$ and $+\mathrm{x}+$ fo $\mathrm{r}+\mathrm{x} \% 3 \mathrm{D} 0+$ to +1 [https://perma.cc/UK3Z-DU46] (last visited Apr. 12, 2016).

120. See Lottery Sales and Transfers, N. Am. Ass'N ST. \& Provincial LOTTERIES, http://www.naspl.org/index.cfm?fuseaction=content\&menuid=17\&pageid= 1025 [https://perma.cc/B7UB-AJ9T] (last visited Apr. 12, 2016) [hereinafter National Lottery Data].

121. Derek Thompson, Lotteries: America's $\$ 70$ Billion Shame, ATLANTIC (May 11, 2015), http:/www.theatlantic.com/business/archive/2015/05/lotteriesamericas-70-billion-shame/392870 [https://perma.cc/XAJ7-P49G].

122. See National Lottery Data, supra note 120.

123. See Charles T. Clotfelter et al., State Lotteries at the Turn of the Century: Report to the National Gambling Impact Study Commission 13 (1999), http://govinfo.library.unt.edu/ngisc/reports/lotfinal.pdf [https://perma.cc/6ZUZEXZD] (reporting that "lottery expenditures represent a much larger burden on the household budget for those with low incomes than for those with high incomes"). 
the regular purchase of lottery tickets as a form of savings. ${ }^{124}$ Even the economic impact of winning the lottery falls far short of being unambiguously positive. ${ }^{125}$

The yearning for lotteries is sufficiently powerful that banks and credit unions, with the strong backing of advocates for higher levels of savings and financial literacy among the poor, have resorted to depositor lotteries to induce lower- to middle-income customers to open and fund savings accounts. ${ }^{126}$ Although prize-linked savings accounts are illegal in states that treat them as nonsanctioned lotteries, they are prevalent around the world. ${ }^{127}$ They operate on the same principle as lottery bonds, typically issued by a sovereign that promises to redeem a select number of bonds (substantially) above face value. ${ }^{128}$ The practice is actually quite old, with American ${ }^{129}$ and European ${ }^{130}$ antecedents predating the twentieth century. The oldest lottery bond may be the United Kingdom's "Million Adventure" of 1694, a lottery intended to retire debt from the then-ongoing Nine Years' War (1689-1697). ${ }^{131}$

124. See Tina Rosenberg, Playing the Odds on Savings, N.Y. Times (Jan. 15, 2014), http://opinionator.blogs.nytimes.com/2014/01/15/playing-the-odds-on-saving [https://perma.cc/F5PA-GL9Z].

125. See generally Guido W. Imbens, Donald B. Rubin \& Bruce I. Sacerdote, Estimating the Effect of Unearned Income on Labor Earnings, Savings, and Consumption: Evidence from a Survey of Lottery Players, 91 AM. ECON. REV. 778 (2001) (finding that unearned income from lotteries reduces labor earnings, especially for players between 55 and 65 years old, and that lottery winners saved approximately $16 \%$ of their proceeds).

126. See generally Melissa S. Kearney et al., Making Savers Winners: An Overview of Prize-Linked Savings Products, in FinANCIAL LITERACY: IMPLICATIONS For Retirement Security and the Financial MarketPlace 218, 218-19 (Olivia S. Mitchell \& Annamaria Lusardi eds., 2011).

127. See Mauro F. Guillén \& Adrian E. Tschoegl, Banking on Gambling: Banks and Lottery-Linked Deposit Accounts, 21 J. Fin. SERV. Res. 219, 219 (2002).

128. See, e.g., Bjarne Florentsen \& Kristian Rydqvist, Ex-Day Behavior When Investors and Professional Traders Assume Reverse Roles: The Case of Danish Lottery Bonds, 11 J. Fin. InTERMEDIATION 152, 155 (2002); Richard C. Green \& Kristian Rydqvist, Ex-Day Behavior with Dividend Preference and Limitations to Short-Term Arbitrage: The Case of Swedish Lottery Bonds, 53 J. FIN. ECON. 145, 150 (1999).

129. See Charles W. Calomiris, The Motives of U.S. Debt-Management Policy, 1790-1880: Efficient Discrimination and Time Consistency, 13 REs. ECON. Hist. 67, 68-69 (1991); Robert M. Jennings, Donald F. Swanson \& Andrew P. Trout, Alexander Hamilton's Tontine Proposal, 45 WM. \& MARY Q. 107, 108 (1988).

130. See Henri Lévy-Ullmann, Lottery Bonds in France and in the Principal Countries of Europe, 9 HARV. L. REV. 386, 387 (1896).

131. See Anne L. Murphy, Lotteries in the 1690s: Investment or Gamble?, 12 Fin. Hist. REV. 227, 231-34 (2005) (describing the Million Adventure as an offering of 


\section{B. Private Equity}

At the opposite end of the socioeconomic spectrum from statesponsored lotteries, wealthier households indulge in private equity. Skewness preference may explain why anyone willingly invests large amounts in a single privately held firm, ${ }^{132}$ despite a wretched tradeoff between risk and return. Returns on private equity are typically no better than those on publicly traded stocks, and high correlation with public equity reduces any diversification value that private equity might otherwise offer. ${ }^{133}$

Investment in private equity, to say the least, is "extremely concentrated": "About 75 percent of all private equity is owned by households for whom it constitutes at least half of their total net worth."134 Households holding "entrepreneurial equity invest on average more than 70 percent of their private holdings in a single private company in which they have an active management interest." "135 In many households, "income from entrepreneurial ventures"-more generally designated as "proprietary business income"-_represents a large source of undiversifiable risk that is more highly correlated with common stock returns."136

In exchange for this "dramatic lack of diversification," to say nothing of the risk inherent in aligning returns from investment with highly compensated but easily terminated personal labor, private equity investors realize "rather unimpressive" returns that are "no higher than the market return on all publicly traded equity." 137 Ownership of entrepreneurial equity therefore constitutes not so much an exercise in staking out a personalized corner along the

100,000 tickets at $£ 10$ each, with $2.5 \%$ (or 2,500) paying prizes ranging from $£ 10$ per year to $£ 1,000$ per year for 16 years); accord Kearney et al., supra note 126, at 223.

132. See Todd Mitton \& Keith Vorkink, Equilibrium Underdiversification and the Preference for Skewness, 20 REV. FIN. STUD. 1255, 1255-56 (2007); cf. John Y. Campbell, Household Finance, 61 J. FIN. 1553, 1564 (2006) (observing that private business assets take the place of public equity holdings in many wealthy households); William M. Gentry \& R. Glenn Hubbard, Entrepreneurship and Household Saving, 4 AdVANCES ECON. ANALYSIS \& POL'y 1, 8 (2004).

133. See Tobias J. Moskowitz \& Annette Vissing-Jørgensen, The Returns to Entrepreneurial Investment: A Private Equity Premium Puzzle?, 92 AM. Econ. Rev. 745, 745-46 (2002).

134. Id. at 745 .

135. Id.

136. John Heaton \& Deborah Lucas, Portfolio Choice and Asset Prices: The Importance of Entrepreneurial Risk, 55 J. FIN. 1163, 1163 (2000).

137. Moskowitz \& Vissing-Jørgensen, supra note 133, at 745. 
efficient frontier, but rather a plunge off that frontier in search of extreme skewness. Older households, at least, do seem to understand the risk inherent in relying too heavily on proprietary business income. As households age, they "tend to move to safer assets, by substituting riskier proprietary business ownership with stocks, bonds, and especially cash." 138

\section{Equity Crowdfunding}

Among species of private equity, perhaps none captures academic and popular attention as vividly as equity crowdfunding. ${ }^{139}$ Before 2012, Regulation D of the Securities and Exchange Commission (SEC), ${ }^{140}$ the traditional exemption that facilitated the offering of securities without SEC registration, made "private placement exemptions" from federal securities laws "generally unavailable for crowdfunding transactions."

In particular, the SEC's definition of an "accredited investor" 142 put Regulation D beyond the reach of most crowdfunding efforts, which are not intended to "be limited to investors that meet specific qualifications." 143 Natural persons (as opposed to corporations and other business or nonprofit entities) seeking to qualify as accredited investors must either (1) have a net worth, either alone or with a spouse, exceeding $\$ 1$ million without the benefit of equity in a primary residence, ${ }^{144}$ or (2) report individual income exceeding

138. Heaton \& Lucas, supra note 136, at 1168.

139. See generally, e.g., Ajay K. Agrawal, Christian Catalani \& Avi Goldfarb, Some Simple Economics of Crowdfunding (Nat'l Bureau of Econ Research, Working Paper No. 19133, 2013), http://www.nber.org/papers/w19133 [https://perma.cc/3NRL-7P3M]; Paul Belleflamme, Thomas Lambert \& Armin Schwienbacher, Crowdfunding: Tapping the Right Crowd, 29 J. Bus. Venturing 585 (2014); C. Steven Bradford, Crowdfunding and the Federal Securities Laws, 2012 Colum. Bus. L. REV. 1 (2012). The popular literature on crowdfunding is deep. The title of Gary Spirer, Crowdfunding: The Next Big Thing (2014), conveys the sense of breathless anticipation that characterizes that body of work.

140. Regulation D, Limited Offer and Sale of Securities Without Registration Under the Securities Act of 1933, 17 C.F.R. $\S \S 230.500-.508$ (2016).

141. Crowdfunding, 80 Fed. Reg. 71,388, 71,389 (Nov. 16, 2015) (final rule to be codified at 17 C.F.R. pts. 200, 227, 232, 239, 240, 249, 269, and 274) [hereinafter Final Crowdfunding Rule].

142. 17 C.F.R. $§ 230.501(a)$; see also SEC, OfF. Inv. Educ. \& Advoc., ACCREDITED INVESTORS (n.d.), http://www.investor.gov/sites/default/files/ib accreditedinvestors.pdf [https://perma.cc/9CAG-3EH2].

143. Final Crowdfunding Rule, supra note 141, at 71,389.

144. 17 C.F.R. $\S 230.501(a)(5)$. 
$\$ 200,000$ or joint income with a spouse exceeding $\$ 300,000$ "in each of the two most recent years ... and ha[ve] a reasonable expectation of reaching the same income level in the current year." 145 One journalistic source estimated that there were 8.5 million accredited investors in the United States in 2014. ${ }^{146}$

Congress passed the Jump Our Business Startups Act of 2012 (JOBS Act $)^{147}$ in order to establish "a regulatory structure for startups and small businesses to raise capital" using Internet-based equity crowdfunding. ${ }^{148}$ The JOBS Act was intended to reduce the cost of "making relatively low dollar offerings of securities, featuring relatively low dollar investments by the "crowd." 149 At the same time, the JOBS Act also sought "to protect investors who engage" in equity crowdfunding transactions by imposing "investment limits" and requiring intermediaries to make disclosures to investors and potential investors..$^{150}$

In concert with the SEC's final crowdfunding rule (promulgated on November 16, 2015), ${ }^{151}$ the JOBS Act exempts qualifying equity crowdfunding transactions ${ }^{152}$ from registration requirements that would otherwise be applicable under $\S 5$ of the Securities Act of 1933. ${ }^{153}$ Exempted crowdfunding securities must raise no more than $\$ 1$ million in any twelve-month period. ${ }^{154}$ Individual investments in all crowdfunding issuers in a 12-month period are limited to "[t]he greater of $\$ 2,000$ or 5 percent of the lesser of the investor's annual income or net worth if either the investor's annual income or net worth is less than $\$ 100,000 .{ }^{\prime 55} \mathrm{~A}$ higher limit of " 10 percent of the lesser of the investor's annual

145. Id. at $\S 230.501(\mathrm{a})(6)$.

146. See Devin Thorpe, SEC Mulls Changes to Accredited Investor Standards, 18 Crowdfunders React, ForBES, (July 15, 2014), http://www.forbes.com/sites/ devinthorpe/2014/07/15/sec-mulls-changes-to-accredited-investor-standards-18-

crowdfunders-react [https://perma.cc/5UQN-272S] (crediting "SeedInvest, an equity crowdfunding site" with that information).

147. Jumpstart Our Business Startups Act, Pub. L. No. 112-106, 126 Stat. 306 (2012).

148. Final Crowdfunding Rule, supra note 141, at 71,388.

149. Id.

150. Id. at 71,388-89.

151. See id. at 71,537-38 (outlining a new regulatory provision to be codified at 17 C.F.R. $\S 227.100(2016))$.

152. See 15 U.S.C. $\S 77 d(a)(6)$ (2012) (codifying a new $\S 4(a)(6)$ of the Securities Act of 1933).

153. See id. $\$ 77 \mathrm{e}$.

154. See 17 C.F.R. $\S 227.100(a)(1)$.

155. Id. $\S 227.100(\mathrm{a})(2)(\mathrm{i})$. 
income or net worth, not to exceed an amount sold of $\$ 100,000$," applies "if both the investor's annual income and net worth are equal to or more than $\$ 100,000 . " 156$

Qualifying equity crowdfunding transactions must be conducted through either a traditionally registered broker-dealer or "a new type of entity called a "funding portal." 157 The JOBS Act created "funding portals" as online entities that may serve as equity crowdfunding intermediaries ${ }^{158}$ without registering as broker-dealers under the Securities Exchange Act of 1934. ${ }^{159}$ All intermediaries, whether registered as broker-dealers or qualified as exempted funding portals, must provide regulatory disclosures to investors and potential investors in crowdfunding transactions. ${ }^{160}$

As a brand-new regulatory mechanism for private stock placements, the JOBS Act and the SEC's crowdfunding regulations have no track record. The chief executive officer of an equity crowdfunding platform predicts that crowdfunding of all types will raise $\$ 34$ billion in 2016, an amount that would surpass venture capital. ${ }^{161}$ What is all but certain is that the companies covered by this new mechanism will be offering the lowest-capitalized, least liquid, and most starkly skewed securities in the universe of investment opportunities. In some respects, the income restrictions under the crowdfunding rules are even more stringent than those adopted by Regulation D's definition of an accredited investor, in that $\$ 100,000$ in annual income rather than $\$ 200,000$ constitutes a meaningful regulatory boundary. It takes very little confidence to predict that crowdfunded securities, after a few years of interaction, will rank among the most highly skewed investment opportunities.

156. Id. $\S 227.100(\mathrm{a})(2)(\mathrm{ii})$.

157. Final Crowdfunding Rule, supra note 141, at 71,389; accord 17 C.F.R. $\S 227.100(\mathrm{a})(3)$.

158. See 15 U.S.C. $\S 78 \mathrm{c}(\mathrm{h})(2012)$ (codifying a new $\S 3(\mathrm{~h})$ of the Exchange Act of 1934).

159. See id. $\S 780(a)(1)$ (also known as $\S 15(a)(1)$ of the Exchange Act).

160. See id. $\S 77$ d-1 (codifying a new $\S 4$ A of the Securities Act); 17 C.F.R. $\S 227.201(2016)$.

161. See Chance Barnett, SEC Approves Title III of JOBS Act, Equity Crowdfunding with Non-Accrediteds, ForBES (Oct. 30, 2015), http://onforb.es/ 1WlWtM4 [https://perma.cc/84KQ-QFW4]. 
D. The Underpricing of Conglomerates

Single-segment firms are more highly skewed than highly diversified conglomerates operating in the same industry. ${ }^{162}$ Consequently, conglomerates trade at a discount relative to their single-segment counterparts and offer higher average returns in the long run. ${ }^{163}$

\section{E. Stock Options}

The allure of a large potential payoff explains the prevalence of stock options rather than stock as such in executive ${ }^{164}$ and nonexecutive ${ }^{165}$ compensation packages. ${ }^{166}$ This is merely a variation on the more common tendency of employees to eschew diversification in their retirement accounts, to the point that some 401(k) accounts consist entirely of a stock whose correlation with the investor's labor income approaches $100 \%{ }^{167}$

F. "Death and Jackpot"

Firms teetering on the verge of default, unsurprisingly, offer abnormally low returns. ${ }^{168}$ Controlling for size and value, studies have shown that bankruptcy risk is not rewarded by higher

162. See Philip G. Berger \& Eli Ofek, Diversification's Effect on Firm Value, 37 J. Fin. ECON. 39, 47-48 (1995); Larry H.P. Lang \& René M. Stulz, Tobin's q, Corporate Diversification, and Firm Performance, 102 J. PoL. ECON. 1248, 1259 (1994).

163. See Todd Mitton \& Keith Vorkink, Why Do Firms with Diversification Discounts Have Higher Expected Returns?, 45 J. Fin. \& Quantitative ANALYsis 1367, 1367 (2010).

164. See Ingolf Dittmann, Ernst Maug \& Oliver Spalt, Sticks or Carrots? Optimal CEO Compensation When Managers Are Loss Averse, 65 J. Fin. 2015, 2016 (2010).

165. See Oliver G. Spalt, Probability Weighting and Employee Stock Options, 48 J. Fin. \& QuANTitative ANALYsis 1085, 1086 (2013).

166. See generally Brian H. Boyer \& Keith Vorkink, Stock Options as Lotteries, 69 J. FIN. 1485 (2014).

167. Cf. Robert J. Shiller, Irrational Exuberance 169 (3d ed. 2015) (observing that the propensity to overinvest in company stock stems from the fact that employees tend to "know more stories about their own companies"); Shlomo Benartzi et al., The Law and Economics of Company Stock in 401(k) Plans, 50 J.L. \& Econ. 45 (2007); James M. Poterba, Employer Stock and 401(k) Plans, 93 AM. ECON. REV. 398 (2003).

168. See John Y. Campbell, Jens Hilscher \& Jan Szilagyi, In Search of Distress Risk, 63 J. FIN. 2899, 2899 (2008). 
subsequent returns. ${ }^{169}$ Because these firms also offer a relatively higher probability of extremely large payoffs, however, they excel in attracting individual investors (predominantly naïve noise traders), but not more sophisticated institutional investors that presumably trade on information, to a financial game of "death and jackpot." 170

Jackpots, indeed. Certain investors approach the stock market as if finance resembled the lottery and other forms of overt gambling. ${ }^{171}$ One study found that large lottery jackpots in Taiwan decreased trading volume among stocks preferred by individual investors, especially in stocks with highly skewed, lottery-like returns. ${ }^{172}$ Over-the-counter stocks are known to have extremely negative average returns. ${ }^{173}$ Skewness preference provides the only plausible explanation for the willingness of some investors to sink money in the "pink sheets." 174

At least in the movies, "[p]lot lines within the genre" of gambling stories are not only simple - "the gambler falls into debt; the gambler goes after one big score to get even; the gambler either does or does not get even"-but also offer some chance of redemption as long as "the filmmaker sees gambling as . . . a charming hustle" rather than "a catastrophic vice." 175 By contrast, gambling in any number of real-life venues - casinos, racetracks, state-sponsored lotteries, the pink sheets, one-week fantasy sportshas an even simpler narrative: the house always wins.

The inescapable implication is that trading in stocks, at least for some investors, is a thrilling form of gambling, interchangeable with other forms of risk-seeking entertainment. ${ }^{176}$ Such thrill seeking may

169. See Ilia D. Dichev, Is the Risk of Bankruptcy a Systematic Risk?, 53 J. FIN. 1131, 1131 (1998).

170. See Jennifer Conrad, Nishad Kapadia \& Yuhang Xing, Death and Jackpot: Why Do Individual Investors Hold Overpriced Stocks?, 113 J. FIN. ECON. 455, 455 (2014).

171. See Meir Statman, Lottery Players/Stock Traders, 58 Fin. AnALYsts J. 14, 14-15 (2002).

172. See Xiaohui Gao \& Tse-Chun Lin, Do Individual Investors Treat Trading as a Fun and Exciting Gambling Activity? Evidence from Repeated Natural Experiments, 28 REV. Fin. STUD. 2128, 2128 (2015).

173. See Bjørn Eraker \& Mark Ready, Do Investors Overpay for Stocks with Lottery-Like Payoffs? An Examination of the Returns of OTC Stocks, 115 J. Fin. ECON. 486, 486 (2015).

174. See id. at 503 .

175. Jay Caspian Kang, The Perfect Predictability of Gambling Movies, N.Y. Times MAG. (Oct. 5, 2015), http://nyti.ms/1j109Ro.

176. See generally Nicholas Barberis, A Model of Casino Gambling, 58 Mgmt. ScI. 35 (2012); Daniel Dorn \& Paul Sengmueller, Trading as 
even be detectable through neural scans (functional magnetic resonance imaging) of brain activity during trading. ${ }^{177}$ At the same time, cognitive bias evidently keeps investors and gamblers from recognizing the rather inconvenient truth that the preference for "positively skewed assets" systematically "lower[s] returns" on those assets, from stocks in general to initial public offerings (IPOs). ${ }^{178}$ Financial assets are subject to the same psychology that affects gambling assets, such as lottery tickets and long-shot bets in horse racing. ${ }^{179}$

Intriguingly, religious differences appear to affect the propensity to gamble. ${ }^{180}$ Although Americans are presumably drawn to positively skewed assets, as people around the world appear to be, the Protestant churches' harsh stance toward gambling suppresses that preference in certain regions of the United States. By contrast, the Catholic Church's "more lenient view of gambling ... makes it easier for people in Catholic regions to act on their preference for skewness." "181 It was a devout Catholic, after all, who framed the choice to believe in God as a wager. ${ }^{182}$ In harmony with these conclusions, a study of health and retirement choices found "noticeable differences in risk tolerance by ... religion." 183 "Protestants are the least risk tolerant, and Jews the most." ${ }^{184}$ Blaise Pascal's Catholics come "about halfway [in] between." 185

Entertainment?, 55 Mgmt. ScI. 591 (2009); Mark Grinblatt \& Matti Keloharju, Sensation Seeking, Overconfidence, and Trading Activity, 64 J. FIN. 549 (2009); Alok Kumar, Who Gambles in the Stock Market?, 64 J. FIN. 1889 (2009).

177. See generally Cary Frydman et. al, Using Neural Data to Test a Theory of Investor Behavior: An Application to Realization Utility, 69 J. FIN. 907 (2014).

178. Brunnermeier, Gollier \& Parker, supra note 94, at 159 \& n.2.

179. See id.; cf. Erik Snowberg \& Justin Wolfers, Explaining the Favorite-Long

Shot Bias: Is It Risk-Love or Misperceptions? 118 J. PoL. ECON. 723, 723 (2010).

180. See Alok Kumar, Jeremy K. Page \& Oliver G. Spalt, Religious Beliefs, Gambling Attitudes, and Financial Market Outcomes, 102 J. FIn. ECON. 671, 671 (2011).

181. Nicholas Barberis, The Psychology of Tail Events: Progress and Challenges, 103 Am. ECON. REV. 611, 615 (2013).

182. See generally Nicholas Rescher, Pascal's Wager: A Study of Practical Reasoning in Philosophical Theology (1985).

183. Robert B. Barsky et. al, Preference Parameters and Behavioral Heterogeneity: An Experimental Approach in the Health and Retirement Study, 112 Q.J. ECONOMICS 537, 550 (1997).

184. Id.

185. Id. 


\section{INITIAL Public OfFerings as a Special CASE}

The pricing of initial public offerings (IPOs) of stock in privately held companies warrants especially close scrutiny. ${ }^{186}$ In the short run, IPOs appear to be underpriced. ${ }^{187}$ A 2002 study concluded that issuers of IPOs on average leave \$9.1 million in wealth "on the table" after the first day of trading, as measured by the number of shares available, times the difference between the first day closing price and the offer price. ${ }^{188}$ The typically sanguine reaction of issuers to so much forgone wealth provides keen insight into prospect theory and, more generally, into behavioral economics. "Contentment at selling an article for one-third of its subsequent value is a rare quality." 189

Such tranquility appears to be a psychological artifact. "Prospect theory predicts that, in most situations occurring in the IPO market, issuers will sum the wealth loss from leaving money on the table with the larger wealth gain on the retained shares from a price jump . . . ."190 In technical terms, issuers are influenced by the "covariance of the amount of money . . . and unanticipated wealth changes. ${ }^{\prime 191}$ In simpler terms, it takes extraordinary emotional energy to get upset over millions left on the table when an IPO has made you a billionaire.

The underpricing of IPOs also affects underwriters. The behavior of underwriters who leave money on the table can also be explained in behavioral terms. Underpriced IPOs indirectly compensate underwriters in two ways. First, they allow underwriters to "reduc[e] . . . marketing costs" in finding buyers for new offerings. ${ }^{192}$ Second, underwriters recoup some of their losses by

186. See, e.g., Jay R. Ritter, The Long-Run Performance of Initial Public Offerings, 46 J. Fin. 3 (1991). See generally, e.g., Initial Public OfFerings: An International Perspective (Greg N. Gregoriou ed., 2006); Robert E. Wright, Reforming the US IPO Market: Lessons from History and Theory, 12 ACCT. Bus. \& FIN. Hist. 419 (2002).

187. See Ritter, supra note 186, at 3.

188. See Tim Loughran \& Jay R. Ritter, Why Don't Issuers Get Upset About Leaving Money on the Table in IPOs?, 15 REV. FIN. STUD. 413, 414 (2002).

189. Richard A. Brealey \& Stewart C. Myers, Principles of Corporate FinANCE 389 (5th ed. 1996); accord Loughran \& Ritter, supra note 188, at 414.

190. Loughran \& Ritter, supra note 188, at 414.

191. Id.

192. Id. at 416; see also Alexander Ljungqvist \& William J. Wilhelm, Jr., Does Prospect Theory Explain IPO Market Behavior?, 60 J. FIN. 1759, 1759-60 (2005) (concluding that underwriters defer their compensation by extracting higher 
steering investors to affiliated brokerages, who extract frothy commissions from IPO purchasers who rarely object to paying inflated fees in exchange for access to the offering. ${ }^{193}$ In short, "the opportunity cost of leaving money on the table [is] less important" to underwriters "than the direct fees." 194

Not all IPOs are created alike. The distribution of initial public offerings is lopsided. IPOs undergoing downward revisions average $4 \%$ returns on their first day, while IPOs experiencing upward revisions return an average of $32 \%$ on the first day. ${ }^{195}$ Underpriced IPOs tend to run together in "hot issue" cycles "lasting many months at a time, in which the average initial return is much higher" than at other times. ${ }^{196}$ " $[\mathrm{I}] \mathrm{n}$ the long run," however, "initial public offerings appear to be overpriced." 197 The reason subsists in investor psychology: IPO "investors are irrationally over optimistic about the future potential of certain industries." ${ }^{198}$ Ultimately, notwithstanding the initial underpricing of IPOs (at least relative to the offer price that would have left none of the issuer's money on the table), investors as a class overpay for IPOs in the long run. ${ }^{199}$

As the nearest cousins to lotteries in highly liquid, publicly regulated stock markets, initial public offerings exhibit long-run

fees from satisfied IPO participants-issuers and purchasers alike-in future transactions).

193. See Loughran \& Ritter, supra note 188 , at 416.

194. Id. (citing Richard H. Thaler, Towards a Positive Theory of Consumer Choice, 1 J. ECON. BeHAV. \& ORG. 39 (1980)).

195. See Kathleen Weiss Hanley, The Underpricing of Initial Public Offerings and the Partial Adjustment Phenomenon, 34 J. FIN. ECON. 231, 235-37 (1993); see also Michel A. Habib \& Alexander P. Ljungqvist, Underpricing and Entrepreneurial Wealth Losses in IPOs: Theory and Evidence, 14 REV. FIN. STUD. 433, 433-34 (2001).

196. Ritter, supra note 186, at 3. See generally Roger G. Ibbotson, Jody L. Sindelar \& Jay R. Ritter, The Market's Problems with the Pricing of Initial Public Offerings, 7 J. APPLIED CORP. FIN. 66 (1994).

197. Ritter, supra note 186, at 3 (emphasis added).

198. Id. at 4. See generally Edward M. Miller, Risk, Uncertainty, and Divergence of Opinion, 32 J. FIN. 1151 (1977); cf. Robert J. Shiller, Speculative Prices and Popular Models, 4 J. ECON. PERSP. 55, 56 (1990) (describing the vulnerability of naïve investors to fads).

199. See Reena Aggarwal \& Pietra Rivoli, Fads in the Initial Public Offering Market?, 19 FIN. MGMT. 45, 55-56 (1990) (finding negative returns to investors who buy stock in an IPO and hold it for one year and even more negative returns to investors who buy stock in early aftermarket trading immediately after an IPO and hold that stock for one year). 
pricing anomalies consistent with prospect theory. ${ }^{200}$ An economy containing investors reacting according to the predictions of prospect theory allows IPOs to "be overpriced [to] earn ... low average return[s]," because those investors "value[] . . highly" the chance, even if it is very small, "of a very large return." ${ }^{201}$ The higher the predicted skewness of an IPO, the lower its expected long-run return. ${ }^{202}$ There are also intriguing relationships between the pricing of IPOs, on one hand, and the even-numbered moments on the distribution of returns on IPOs. Volatility is negatively related to subsequent returns on IPOs; kurtosis, by contrast, is positively related. ${ }^{203}$

There is some disagreement over the plausibility of this account of IPOs' long-run underperformance. One source mildly disputes the ability of skewness preference to provide a complete explanation for the long-run underperformance of IPOs. ${ }^{204}$ Five-year returns to IPOs are higher for venture-backed firms than for firms not backed by venture capital. ${ }^{205}$ "Because small nonventure-backed IPOs are more likely to be held by individuals, bouts of investor sentiment are a possible explanation" for these firms" "severe underperformance." 206 "Individuals are arguably more likely to be influenced by fads or lack complete information." ${ }^{207}$ It is true that returns on small IPOs covary with the discount on closed-end funds, which is considered another benchmark of investor sentiment. ${ }^{208}$ Ultimately, however, this critique concludes that "[u]nderperformance is a characteristic of small, low book-to-market firms regardless of whether they are IPO firms." 209

200. See, e.g., Nicholas Barberis, Ming Huang \& Tano Santos, Prospect Theory and Asset Prices, 116 Q.J. ECON. 1, 16-17 (2001).

201. Barberis \& Huang, supra note 115, at 2091.

202. See T. Clifton Green \& Byoung-Hyoun Hwang, Initial Public Offerings as Lotteries: Skewness Preference and First-Day Returns, 58 MGMT. SCI. 432, 432 (2012).

203. See Jennifer Conrad, Robert F. Dittmar \& Eric Ghysels, Ex Ante Skewness and Expected Stock Returns, 68 J. Fin. 85, 120 (2013).

204. See Alon Brav \& Paul A. Gompers, Myth or Reality? The Long-Run Underperformance of Initial Public Offerings: Evidence from Venture and Nonventure Capital-Backed Companies, 52 J. FIN. 1791, 1820 (1997).

205. See id. at 1791.

206. Id. at 1792 .

207. Id.

208. See id. See generally Charles M. C. Lee, Andrei Shleifer \& Richard H. Thaler, Investor Sentiment and the Closed-End Fund Puzzle, 46 J. FIN. 75 (1991).

209. Brav \& Gompers, supra note 204, at 1792. 
On balance, IPO returns follow the fault lines of heterogeneity within the class of investors and among financial intermediaries. IPOs seeking to attract more sophisticated investors require higher returns to attract the interest of investors trading on the basis of information rather than faddishness, emotional affinity, or unfiltered speculation. ${ }^{210}$ Prestigious underwriters are associated with lowerrisk offerings, which leave less money on the table (to the benefit and delight of issuers as well as underwriters) and therefore lower the returns to IPO investors in the long run. ${ }^{211}$ These traits of initial public offerings demonstrate that the investor preferences predicted by prospect theory may be reconciled with the conventional capital asset pricing model. ${ }^{212}$

\section{CONCLUSION}

Prospect theory and the generalized higher-moment capital asset pricing model, as depicted in this Article, provide an overarching view of less than fully rational investor behavior. Neoclassical economics and the conventional approach to "law and economics" born of this tradition have historically confined themselves to stylized facts and hypothethical decision-making mechanisms. Because "[m]ost economists view[ed] their discipline as one that deals with ideally rational behavior," they generally "attach[ed] little significance to discrepancies between what the theory predicts and what people actually do." ${ }^{213}$ Neither actual markets nor behaviorally mediated responses to those markets sustain such a sanitized economic vision. Neither finance nor law

210. See Richard Carter \& Steven Manaster, Initial Public Offerings and Underwriter Reputation, 45 J. FIN. 1045, 1045 (1990).

211. See id. at 1046; Randolph P. Beatty \& Jay R. Ritter, Investment Banking, Reputation, and the Underpricing of Initial Public Offerings, 15 J. FIN. ECON. 213, 216 (1986); cf. Randolph P. Beatty, Auditor Reputation and the Pricing of Initial Public Offerings, 64 AcCT. ReV. 693, 693 (1989).

212. See Barberis \& Huang, supra note 115, at 2068, 2073-74; Enrico De Giorgi, Thorsten Hens \& Haim Levy, CAPM Equilibria with Prospect Theory Preferences (Working paper, 2011), http://ssrn.com/abstract $=420184$ [https://perma.cc/CC29-M23K].

213. Lola L. Lopes \& Gregg C. Oden, The Role of Aspiration Level in Risky Choice: A Comparison of Cumulative Prospect Theory and SP/A Theory, $43 \mathrm{~J}$. MATH. PSYCH. 286, 310 (1999). 
lives by rationality alone, but by every passion that "animate[s] people's ideas and feelings, their animal spirit." ${ }^{14}$

Abnormality, in the sense of statistically significant departures from Gaussian assumptions, is the modal condition of capital markets. ${ }^{215}$ Confronted with volatility, spillover, and contagion, and perhaps even touched by an awareness of profound limits on the human ability to detect deep financial threats, human actors take refuge in time-worn albeit imperfectly rational heuristics: mental accounting, subjective weighting of probabilities, systematic disregard of correlation. ${ }^{216}$

As Tversky and Kahneman have said of prospect theory, even if humans make choices that are "not always rational in the traditional sense," behavioral decision-making is neither "chaotic" nor "intractable," but rather is "orderly" according to its own criteria. ${ }^{217}$ The inconvenient fact that neoclassical economics and behavioral finance "may be incompatible" with each other in some circumstances should "not entail relativism of [the] values" with each framework, "only the notion of a plurality of values not structured hierarchically." "'18 "Humanity, with all its limitations, may well be the source of the stability we lack in our more abstract conceptions in the universe of finance." 219

From lotteries to initial public offerings, humans strongly prefer right-skewed financial instruments and opportunities that offer salient possibilities of big upside gains. In concert, prospect theory and the higher-moment capital asset pricing model predict that this preference will often, perhaps even systematically, drive individuals to make investments whose expected value is abnormally low, nil, or even negative. What Tennessee Williams has called "the catastrophe

214. George A. Akerlof \& Robert J. Shiller, Animal Spirits: How Human Psychology Drives the Economy, AND Why That Matters For Global CAPITALism 1 (2009).

215. See James Ming Chen, Legal Quanta: A Mathematical Romance of Many Dimensions, 2016 Mich. ST. L. REV. 313, 321-22.

216. See generally James Ming Chen, Finance And the Behavioral PROSPECT: Risk, EXUBERANCE, AND ABNORMAL MARKETS (forthcoming 2016).

217. Tversky \& Kahneman, Advances in Prospect Theory, supra note 50, at 317.

218. IsAiAH Berlin, Alleged Relativism in Eighteenth-Century European Thought, in The CROOKED Timber of Humanity: EsSAYS AND CHAPTERS IN THE History OF IDEAS 73-94, 83 (2d ed. 2013, John Banville foreword).

219. Greg B. Davies \& Arnaud de Servigny, Behavioral Investment Management: An Efficient Alternative to Modern Portfolio Theory, at viii (2012). 
of success"220 - the financial and moral pitfalls inherent in the realization of human desires, or perhaps even in the mere act of wishing - appears to arise from the quantum mechanics of human judgment under uncertainty. Whether the law elects to disrupt the psychophysics of financial decision-making depends on the exercise of a distinct and altogether subjective sort of judgment. As do so many other questions of law and "welfare economics," this choice "ultimately dissolve[s] into a study of aesthetics and morals." 221

220. See Tennessee Williams, The Catastrophe of Success, in N.Y. TIMES, Nov. 30, 1947, reprinted in TenNessee Williams, The Glass Menagerie 99-103 (Robert Bray introd., 1999) (1st ed. 1945).

221. R.H. Coase, The Problem of Social Cost, 3 J.L. \& ECON. 1, 43 (1960). 
of success"220_the financial and moral pitfalls inherent in the realization of human desires, or perhaps even in the mere act of wishing - appears to arise from the quantum mechanics of human judgment under uncertainty. Whether the law elects to disrupt the psychophysics of financial decision-making depends on the exercise of a distinct and altogether subjective sort of judgment. As do so many other questions of law and "welfare economics," this choice "ultimately dissolve[s] into a study of aesthetics and morals." 221

220. See Tennessee Williams, The Catastrophe of Success, in N.Y. TIMES, Nov. 30, 1947, reprinted in Tennessee Williams, The Glass Menagerie 99-103 (Robert Bray introd., 1999) (1st ed. 1945).

221. R.H. Coase, The Problem of Social Cost, 3 J.L. \& Econ. 1, 43 (1960). 


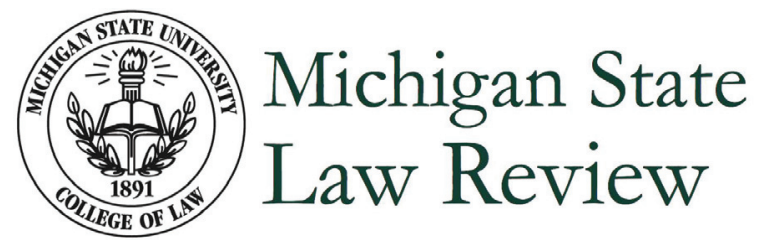




\section{Forthcoming Articles}

The 2016:3 issue will include the following articles from a variety of topics:

Insights from Psychology: Teaching Behavioral Legal Ethics as a Core Element of Professional Responsibility

Tigran W. Eldred

Modern Critiques of Judicial Empathy: A Revised Intellectual History

Brenner Fissell

A Raisin in Reserve: Horne, Takings, and the Problem of Government Price Supports

Mark Klock

\section{Comments}

Inclusionary Zoning: Chicago and the 2015 Affordable Requirements Ordinance

Jonathon Andersh

A Child Without a Country: Dissolving the Statelessness of Children Born Through Surrogacy

Brittany Wolf 